\title{
金属粉末圧粉体の熱間電磁成形と燃焼合成法への応用の試み
}

\author{
佐藤一太郎江1, 日比野 敦行, 根岸 秀明放2
}

的電気通信大学大学院, 干 182 調布市調布ヶ丘1-5-1.

的2 電気通信大学機械制御工学科, $=182$ 調布市調布ヶ丘 $1-5-1$.

\section{Hot Electromagnetic Forming of Metal Powder Compact and its Application to Combustion Synthesis.}

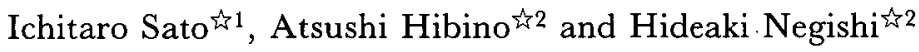 \\ H1 Graduate School, Univ. of Electro-communications, 1-5-1 Chofugaoka, Chofu 182. \\ \{2 Dept. of Mechanical and Control Eng. Univ. of Electro-communications, 1-5-1 Chofugaoka, Chofu 182.
}

Received December 5, 1994

\begin{abstract}
Electromagnetic forming have been used in a field of plastic deformation technology of metal materials. In this paper, dynamic compaction of metal powder by electromagnetic forming under hot conditions was attempted in order to investigate a possibility of electromagnetic pressure sintering. After heating in an electric furnace, a copper powder compact was put into a solenoid coil and a strong pulse current from a condenser bank was passed through the coil.

The compact was shrinked and its density was increased by the electromagnetic pressure of the forming. The degree of densification depended on the charged voltage of the condenser, the capacitance, the current wave form of the coil and the forming temperature. Therefore, the forming process would be applicable to powder pressure sintering.

The process was applied to combustion synthesis of $\mathrm{Ni3} \mathrm{Al}$ intermetallic compound. Ni/Al premixed powder compact was compressed by the forming during its thermal explosion reaction. Consequently, the density was improved in comparison to usual combustion synthesis although the synthesized product cracked.
\end{abstract}

\section{1 緒 言}

電磁成形法(1),(2) とは，被加工物の周囲にコイルを 置き，このコイルに瞬間的な大電流を通して，被加 工物に誘導した電流と磁場との作用力によって材料
を瞬時に成形する塑性加工技術の一種である。この 方法が粉末の焼結に応用できれば圧粉体に対して非 接触で衝撃的な圧縮力を作用させることができ，同 法は新たな加圧焼結の一手法として成り立つと考え 


\section{られる。}

前報(3)ではその可能性を探るため，圧粉体の電磁 成形を試みた。その結果，圧粉体を仮焼結させれば 電磁成形の効果が現れ，圧粉体の密度が向上するこ とが明らかになった。しかし、この結果は室温での 実験によるものであり，同プロセスの詳細な検討の ためには，実条件に近い熱間での電磁成形の実験が 必要と考えられる。そこで本研究では，熱間におけ る電磁成形装置を試作することにし，その装置を用 いて圧粉体の熱間電磁成形を試みることにした。

実験の方針としては，まずCu粉末圧粉体をモデ ル材として基礎的に熱間電磁成形の効果を調べた. ついで，近年新素材の合成法として期待される燃焼 合成法へ本法を適用し，応用面での実験を行った. 以下にその結果を示す.

\section{2 実験方法}

\section{1 実験装置}

本研究では，電気炉と電磁成形装置を組合わせ， 圧粉体を熱間で電磁成形する装置を試作した。 Fig.1にその装置の概略図を示す．電気炉で加熟し た試料をロッドでコイルまで移動させ，電磁力を作 用させる構造とした。その際に, 試料の周囲を石英 管で遮蔽し，真空ポンプで排気して試料が酸化しな いようにした。

この装置で問題となるのが，試料の温度低下であ る、試料を電気炬から取り出し、コイルまで移動さ せると温度が低下してしまう恐れがある。そこで， 予備実験として電気炉からコイルへ移動させたとき

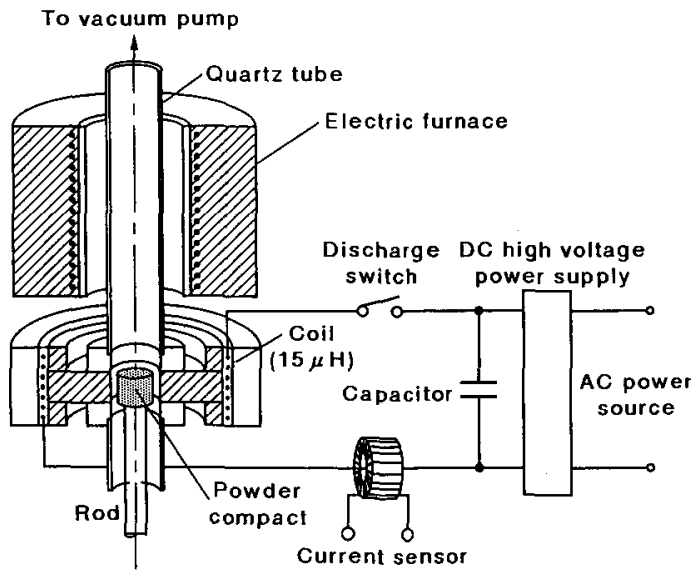

Fig. 1: Schematic drawing of the hot electromagnetic forming equipment.
の試料の冷却曲線を測定した，Fig.2に，相対密度 $45 \% の C u$ の圧粉体について冷却曲線を調べた結果 を示す．試料の温度は，炬から取り出してからの時 間の経過につれ低下することがわかる。しかし，炉 から取り出してからの時間が15秒以内であれば， 温度の低下は 100 C 以内に抑えられるようである。 この偵向は，相対密度58\%の圧粉体でも同様であ る。そこでこの予備実験に基づき，熱間電磁成形時 の温度を予测して以下の実験を行った。

\section{2 ．２試料の作製および実験方法}

原料粉末として平均粒径 $74 \mu \mathrm{m}$ の市販の電解銅粉 を使用した。この粉末を金型に充填し，万能試験機 で圧密して圧粉体を作製した。その際に試験機の荷 重を制御し, 相対密度の異なる数種類の圧粉体を得 た.この圧粉体を真空電気炬にて $600^{\circ} \mathrm{C} ， 30 \mathrm{~min}$ の 条件で仮焼結させ，実験用の試料とした，原理的に は焼結途中で電磁力を作用させれば良いため，生粉 体を仮焼結する必要はない。しかしいきなり圧粉体 を加熱すると，焼結の収縮と電磁成形の寸法变化が 重畳し，電磁成形の効果が把握できない恐れがある. そこで事前に圧粉体を仮焼結させたものを試料とし た.

実験は試料を石英管に入れ，内部を真空に排気し た. 所定温度に制御した電気炉にロッドを押し上げ 試料を加熱した。試料温度が平衡に到達したら素早 くロッドを下げ，試料をコイルにセットした，その 後，事前に充電したコンデンサーから，コイルへ大 電流を通し，試料に電磁力を作用させた，その際の 電磁力は，コンデンサーの充電電圧および容量を変

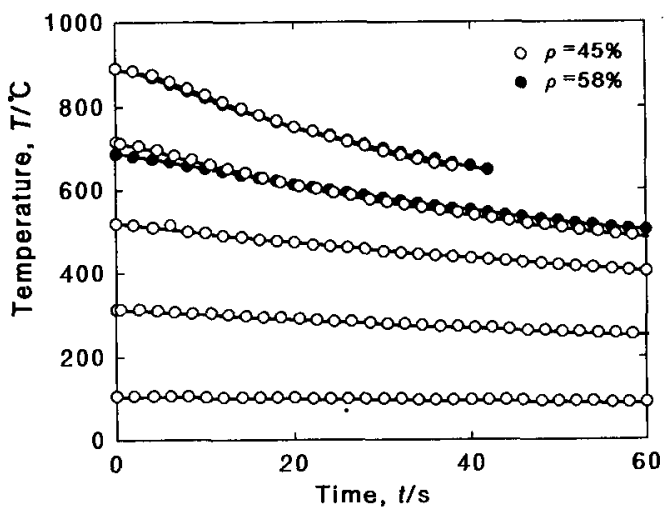

Fig.2: Cooling curves of copper compacts taken out of the electric furnace. 
化させて制御した。なお，コイルに流れる電流は， 回路途中に設けた電流センサーを用いてモニターし た.このようにコイルに大電流を通じることで試料 には誘導電流が励起され，磁場との作用力により試 料は側面から圧縮されることになる. 成形後の試料 について, 寸法および質量を測定し, 電磁成形の密 度変化を計算した。 また, 一部の試料は切断し, 断 面を光学顕微鏡で観察した.

\section{2. $3 \mathrm{Ni}_{3} \mathrm{Al}$ の燃焼合成への電磁成形の適用}

さらに本研究では, $\mathrm{Ni}_{3} \mathrm{Al}$ の燃焼合成法へ本プロ セスの適用を試みた. 粒径 $56 \mu \mathrm{m}$ の Ni粉末と粒径3 $\mu \mathrm{m}$ の $\mathrm{Al}$ 粉末を原子比で $\mathrm{Ni}: \mathrm{Al}=3: 1$ の割合となるよ うボールミル中で混合した.この混合粉末を金型で 圧密して $\mathrm{Ni} / \mathrm{Al}$ 混合圧粉体を作製した。この圧粉体 を上記の熱間電磁成形装置の中で加熱し，着火させ た. 着火が確認されたならば素早くコイルにセット して燃焼合成途中で電磁力を作用させた. その後, 合成体の密度, 組織を測定して, 本プロセスの適用 性について検討した.

\section{3 結果および考察}

\section{3. $1 \mathrm{Cu}$ 粉末圧粉体の熱間電磁成形}

まず，熱間での電磁成形の効果を調べるために， 相対密度 $45 \%$ および63\%の試料について温度 800 ${ }^{\circ} \mathrm{C}$, コンデンサー容量 $400 \mu \mathrm{F}$, 充電電圧 $8 \mathrm{kV}$ の条 件で電磁成形を行った. Fig.3に，その試料の外観 を示す. 図中(a)は電磁成形前の試料であり, (b) と (c) は，それぞれ初期密度 $45 \%, 63 \%$ の試料の電磁成

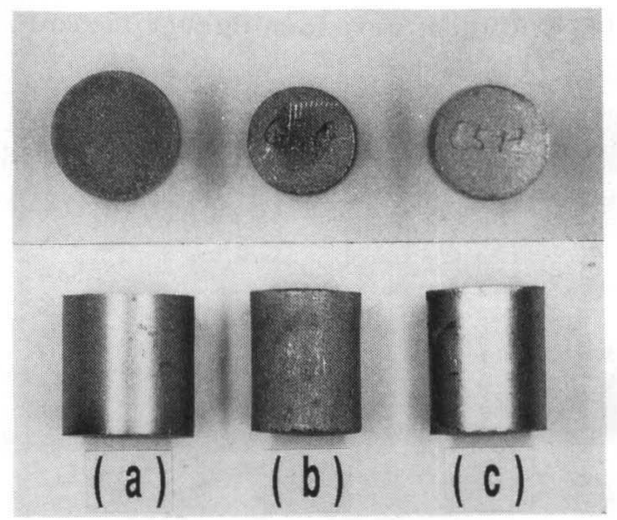

Fig.3: Macro view of the compacts after hot electromagnetic forming. (a) Pre-sintered, (b)After forming (Initial density:45\%), After forming (Initial density:63\%).

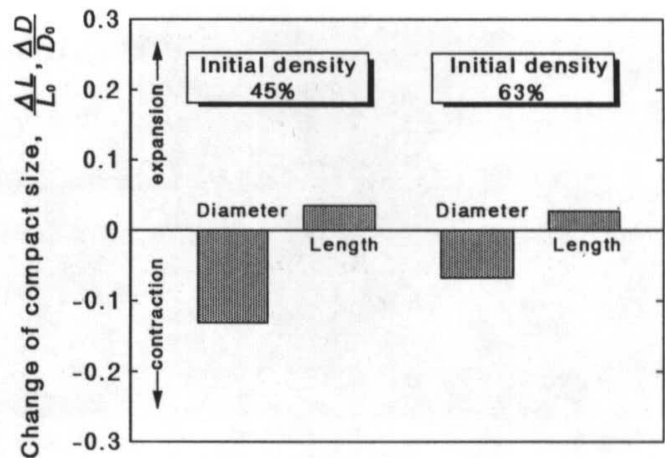

Fig.4: Changes of the compact size by electromagnetic forming.

形後の外観である.このようにCu試料について熱 間で電磁成形を行った結果，試料は圧縮され，その 効果があるということが明らかになった.

Fig.4に, 電磁成形に伴う試料の寸法変化を示す. 試料は直径方向に収縮し，軸方向に伸びることがわ かった．軸方向の伸びは，側面から電磁力を作用さ せたため試料が逃げるためである。しかし本結果で はその逃げは小さく，試料の密度を計算したところ， 初期密度 $45 \%$ の試料では $58 \%$ まで，また密度 $63 \%$ のものでは71\%にまで試料の密度は高められるこ とがわかった。

Fig.5に，この試料の断面を調べた結果を示す. 中心部には密度の高い部分が形成され，緻密化は必 ずしも一様に進行するのではないことがわかった。 このような現象は, 粉末を爆発成形した場合でもみ られる現象であり，衝撃波が中心部に集中するため といわれている(4),(5). 本プロセスでもおそらく衝撃 波の発生でこのような現象が生じたものと推察され る.また，爆発成形では衝撃波の反射や干渉により 希薄波が発生し，圧粉体が破壞される場合があると されている(6),(7). 電磁成形の場合でも，室温では条

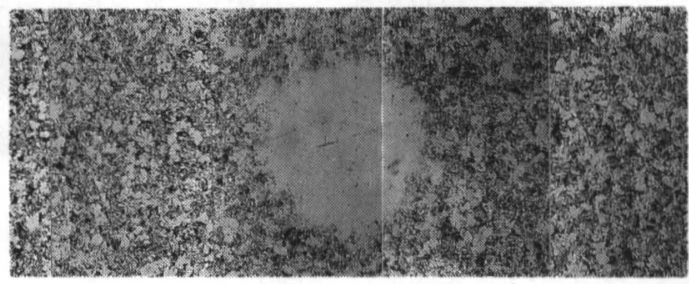

Fig. 5: Cross section of the compact after electromagnetic forming (Initial density:45\%). 


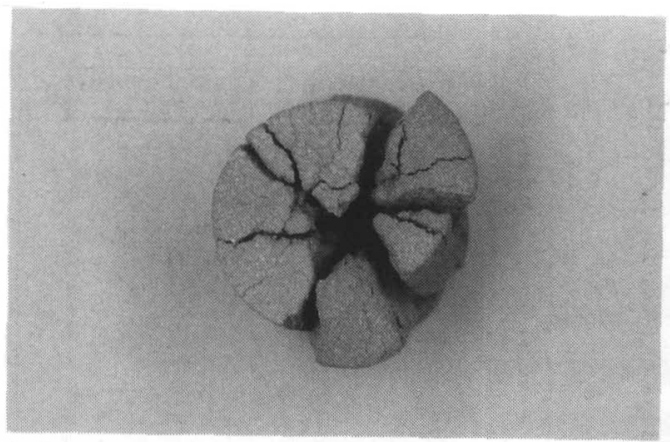

Fig. 6: Crack of the compact caused by electromagnetic forming.

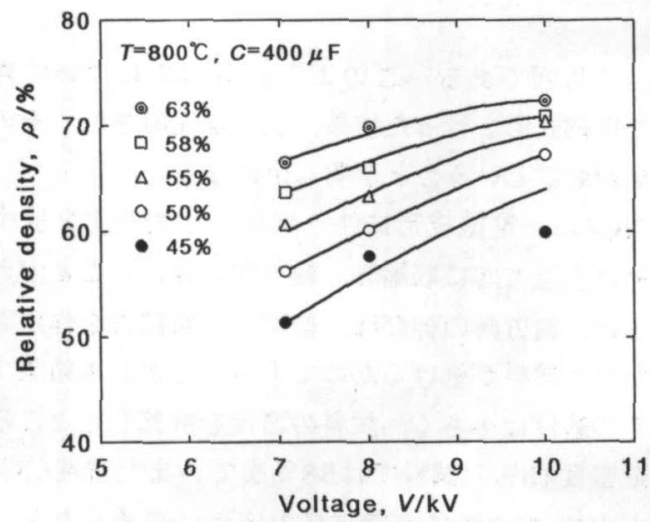

Fig. 7: Relative density of the compacts after electromagnetic forming.

件次第でFig.6のような破壊が発生した.しかし， $800^{\circ} \mathrm{C}$ で電磁成形した場合では試料の破壊は発生せ ず，成形後はいずれもFig.3のような形状となった。 ただし，条件によっては破壊が発生する場合がある と予想され，今後この破壊条件についても検討する 必要がある。

Fig.7に, コンデンサーの充電電圧を変え, 電磁 力を変化させたときの試料の到達密度を示す. 試料 密度は, コンデンサーの充電電圧に対してほほ比例 して高まることがわかった. しかし，最も緻密化し たものでも，到達密度は $72 \%$ にすぎない，従って， より密度を高めるためには，コンデンサーの耐圧を 上げさらに出力を増す，あるいは複数回電磁成形を 繰り返すなど新たな対策も必要である。

\section{2 熱間電磁成形の効率化}

熱間での電磁成形の効率化を図るため, 諸条件の 効果について検討した. Fig.8に，電磁成形時にコ
イルに流れる電流を測定した結果を示す。コイルに 流れる電流は, よく知られているように, 減衰振動 波形となった.この際にコンデンサーの容量および 充電電圧を変化させ,

(a) $V=10.0 \mathrm{kV}, C=200 \mu \mathrm{F},\left(1 / 2 \cdot C V^{2}=10.0 \mathrm{~kJ}\right)$

(b) $V=7.1 \mathrm{kV}, C=400 \mu \mathrm{F},\left(1 / 2 \cdot C V^{2}=10.1 \mathrm{~kJ}\right)$

(c) $V=5.8 \mathrm{kV}, C=600 \mu \mathrm{F},\left(1 / 2 \cdot C V^{2}=10.1 \mathrm{~kJ}\right)$

の条件下でコイル電流を比較させた結果, コンデン サー容量を小さくした (a)の場合では周期の短い波 形が観測され，コンデンサー容量を大きくした(c)の 場合では逆に周期の長い振動波形が見られた.

Fig.9に，これらの条件下で熱間電磁成形を行っ た結果を示す.(a)のように,コンデンサーの容量 を小さくとり，周期を短くした方が, 密度の変化は 大きくなることがわかった.これは周期が短くなる と, コイルの磁束変化が急激になり, 衝撃力が変化 するためと思われる，従って，より高密度を得るた

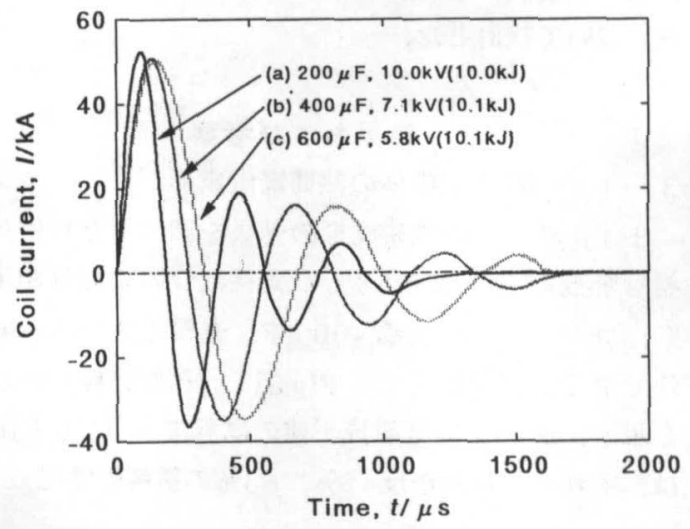

Fig.8: Current wave form through the coil.

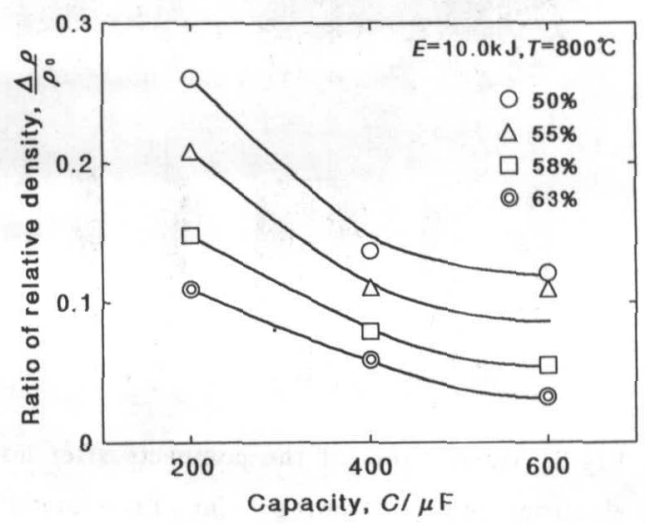

Fig.9: Difference of densification efficiency by current wave form. 
めにはコンデンサー容量を小さくし, 充電電圧を高 くする必要がある.

Fig.10に, 電磁成形時の温度を変化させたときの 密度の変化を示す. 温度を変え電磁成形を行った結 果, 試料の到達密度は温度に応じて変化をすること がわかった.この結果によると, 温度 $400^{\circ} \mathrm{C}$ 付近で は室温よりむしろ成形効率は低くなり，それ以上の 温度域で室温よりも緻密化した。

Fig.11に, 参考值として純Cuバルク材の電気抵抗 率と温度の関係(8)および $0.2 \%$ 降伏応力と温度の関係 (9)を示す. 純 $\mathrm{Cu} 0.2 \%$ 降伏応力は温度の上昇につれ て減少し, 逆に電気抵抗率は上昇につれ大きくなる ことが示されている.このデータでは熱間では材料 は軟化し, 電磁成形には有利となる。しかし逆に, 電気抵抗率は上昇し，不利なことになる．すなわち

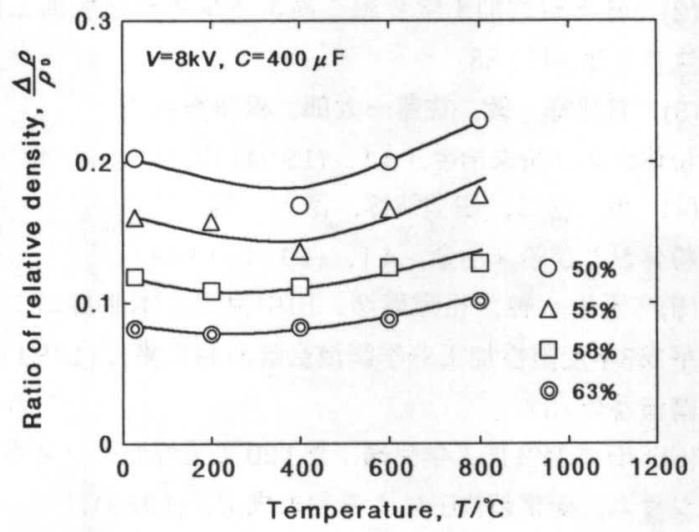

Fig. 10: Difference of densification efficiency for various temperature.

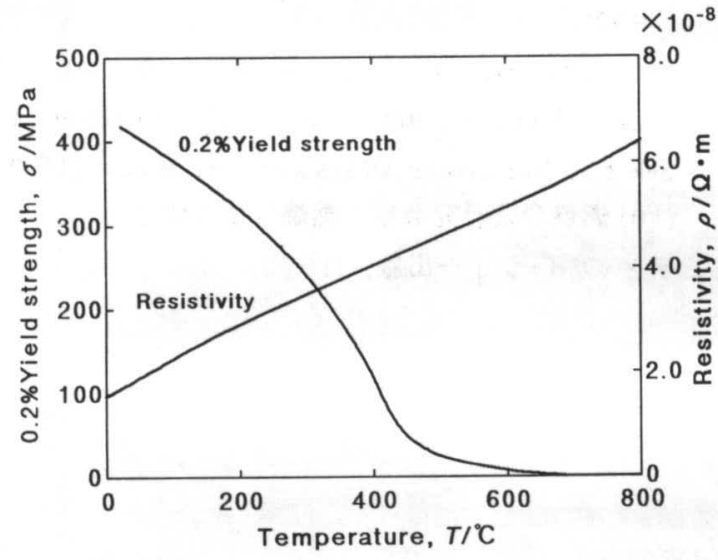

Fig. 11: $0.2 \%$ yield strength and electric resistivity of pure copper.

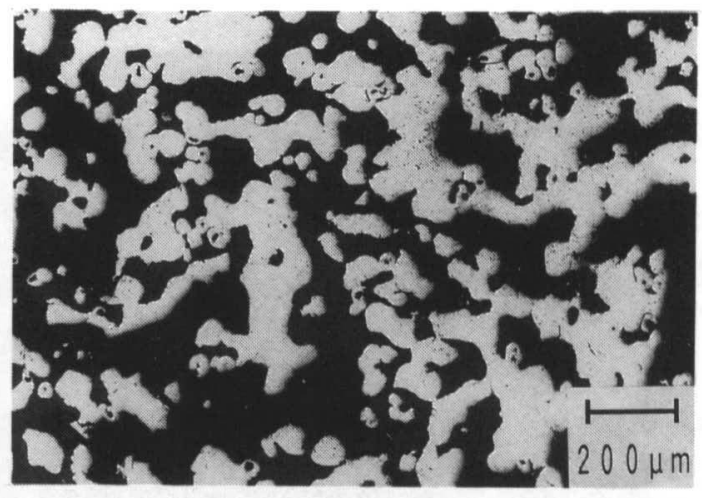

Fig. 12: Typical microstructure of $\mathrm{Ni3} \mathrm{Al}$ intermetallic compound synthesized by combustion synthesis process.

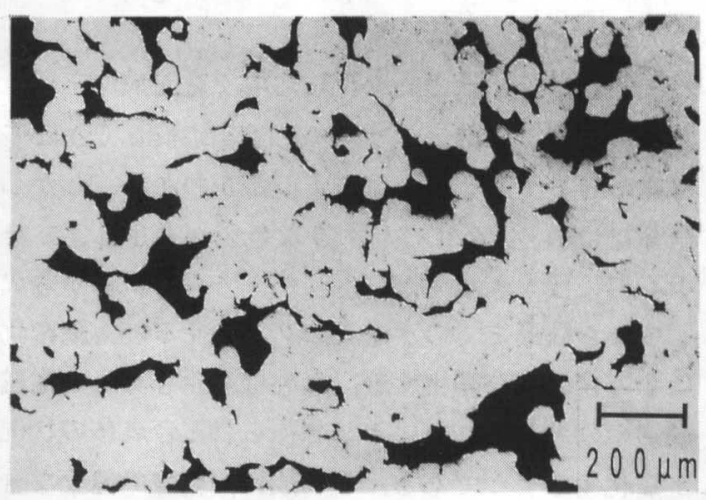

Fig. 13: Microstructure of the synthesized product compressed by electromagnetic forming.

これら両者の相乗効果により，Fig.10のような現象 が現れたものと考えられる. 従って本結果からする と, 熱間での電磁成形には適切な温度域があり,こ の温度を選択して成形を行わなければならないこと が明らかになった.

\section{3. $3 \mathrm{Ni}_{3} \mathrm{Al}$ の燃焼合成への適用}

さらに, 本研究では近年, 金属間化合物の合成法 として期待される燃焼合成法への応用を試みた. $\mathrm{TiAl}$ およびNi ${ }_{3} \mathrm{Al}$ に代表される金属間化合物は, 燃 焼合成法で比較的容易に合成することができるとさ れている(10). しかし，この方法で得られた化合物 は，Fig.12のように多孔質となり，そのままでは実 用に適さない場合が多い。そこで以上の結果をふま え $\mathrm{Ni}_{3} \mathrm{Al}$ の燃焼合成法へ本プロセスを適用すること を試みた. $\mathrm{Ni} / \mathrm{Al}$ 混合圧粉体を熱間電磁成形装置の 中で着火させ, その合成反応途中で電磁成形を行っ 


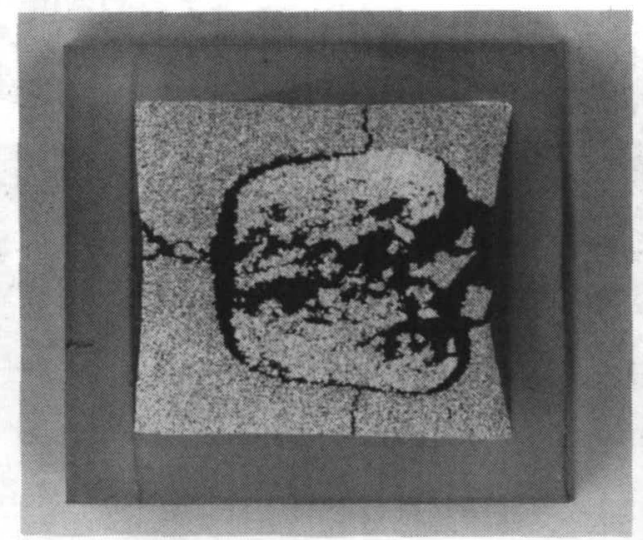

Fig. 14: Cross section of the synthesized product after electromagnetic forming.

た. Fig.13に，その燃焼合成途中で電磁成形を行っ た試料の断面組織を示す. Fig.12と比較して合成体 は緻密化し，空孔が減少することがわかる。しかし 全体にはFig.14のように大きな亀裂が発生し，また 中心部には大きなすが発生した. さらに試料が着火 してから成形までのタイミングをかえると, 緻密化 はするが亀裂が発生する, 亀裂は発生しないが電磁 成形の効果が現れない, など得られる合成体の状況 が変化するようである，それ故に，緻密で健全な合 成体を得るためには今後, 電磁力の大きさ, タイミ ングなど総合的に検討する必要がある。

\section{4 結 言}

1. 熱間での電磁成形装置を試作し, $\mathrm{Cu}$ 仮焼結体 をモテル材として熱間電磁成形法を試みたところ, その効果が確認できた.

2. 電磁成形温度を変化させた結果, 緻密化は温度 に依存することがわかった。これは, 試料の機械的 性質, 電気的性質が温度によって変化するためと考 えられる。

3. $\mathrm{Ni}_{3} \mathrm{Al}$ 金属間化合物の燃焼合成法に本プロセス
の適用を試みた. その結果, 試料は部分的に緻密化 された. しかし試料には大きな亀裂が発生した.

4. 健全な $\mathrm{Ni}_{3} \mathrm{Al}$ 合成体を得るためには電磁成形の タイミングおよびエネルギーなど総合的な検傠が必 要である.

\section{謝 辞}

本研究の一部は, 天田金属加工機械技術振興財団 の研究助成によって行われた. また, 東洋アルミニ ウム株式会社からはA 1 粉末のご提供をいただいた. 紙面を借りて関係の皆様に厚く御礼申し上げる.

\section{文 献}

(1) M. M. Plum: Metals Handbook, 9th edition vol..14, Forming and Forging, Ed. by S. L. Semiatin, ASM Ohio, (1988).

（2）日本塑性加工学会編：高エネルギー速度加工, コロナ社, (1988)

(3) 日比野 敦, 佐藤一太郎, 根岸秀明 : 粉体および粉末冶金, 41，(1994) 623.

（4）段 浩二, 田辺靖博, 澤岡 昭:

粉体および粉末冶金, 41, (1994) 1144.

（5）玉川 純, 相澤 龍彦, 田中克巳, 木原諒二 : 平成3年度塑性加工春季講演会講演論文集, (1991), 講演番号 437 .

（6）日本塑性加工学会編：第120回塑性加工シンポ ジウム, 衝撃超高圧による粉末成形, (1989).

(7) 高島和希, 頓田英機, 上野 學ら:

鉄と鋼, 73, (1987) 2219.

（8）日本金属学会編：金属データブック, 丸善, (1993).

(9) ASM Committee on Copper and Copper Alloys: Metals Handbook, 9th edition vol.2, Properties and Selection Nonferrous Alloys and Pure Metals, (1979). (10) 燃焼合成研究会編: 燃焼合成の化学, ティ・アイ・シィー出版, (1992). 